\title{
Mobile Farming: Level Of Use By Small Scale Farmers In Zimbabwe.
}

\author{
Servious Mbiza (Masters in Information Technology) \\ Faculty of Information Technology, Zimbabwe Open University, Zimbabwe \\ DOI: 10.29322/IJSRP.11.05.2021.p11340 \\ http://dx.doi.org/10.29322/IJSRP.11.05.2021.p11340
}

\begin{abstract}
While the mobile phone has revolutionized some sectors of the economy such as banking, its impact in agriculture in Zimbabwe is yet to be established. For farmers to adapt to the fastchanging global environment and remain competitive and relevant, they must integrate ICTs in their farming activities. The study was carried out on farmers in Mushandike Irrigation Scheme in Masvingo district in Zimbabwe. Because of the farmers' long stay in commercial farming activities, they were clearly aware of their information requirements in farming. Questionnaires were distributed to 54 farmers and interviews were conducted with 10 farmers from the Irrigation Scheme. The level of use of mobile phone applications was found to be very poor. The extension worker was seen as the main source of information when it comes to dealing with traditional issues such as pests and crop diseases. Small scale farmers were not benefitting from mobile applications. The mobile phones were mainly used for voice communications and texting messages, Whatsup, Internet surfing and online banking. Although this kind of utilization is positive for the smallscale farmer, there is still a lot that farmers can benefit from mobile phones. Farmers were not utilizing dedicated or specialized applications. Thorough awareness campaigns should be carried out by government and other stakeholders to enlighten farmers on the benefits of using mobile applications.
\end{abstract}

Index Terms- Mobile farming, use of ICTs in farming, small scale farmers in Zimbabwe, Information needs of small scale farmers in Zimbabwe

\section{INTRODUCTION}

The potential for farming in Zimbabwe is phenomenal yet fifteen years after embarking on the land reform programme most Zimbabwean small-scale farmers have remained poor and the country has remained a basket case. As reported in the Abridged Postal \& Telecommunications Sector Performance Report: Third Quarter 2020, the total number of active mobile subscriptions reached 12,783,785 and the mobile penetration rate reached $87.7 \%$. This was over a population of 13 million in the country. Research by the various authors, show that farming business heavily depends on timely access to information on weather, crop nutrition, inputs, markets, and disease outbreaks. The study is intended to establish the level at which small-scale farmers in Zimbabwe have adopted mobile phones to enhance their farming businesses. It was therefore necessary to study how local farmers were utilizing the available mobile applications to satisfy their information needs in Zimbabwe. A mixture of quantitative and qualitative research methods was used. Questionnaires were distributed to 54 respondents, filled, and returned. Interviews were conducted on 10 of the respondents who had filled the questionnaire. The research managed to establish how farmers were accessing information concerning the three critical areas identified in this research.

\section{REVIEW OF RELATED LITERATURE}

Gichamba and Lukanda (2012) describe mobile farming as the use of mobile devices such as cell phones, Personal Digital Assistants (PDAs), tablets and other handheld communication or computing devices to provide agricultural services and information. As suggested by Parrish et al. (2005), small-scale farmers require information on current prices, forecast of market trends and sales timing. There is increase in specialized mobile services that can fulfil specific agricultural functions. In its Strategic National Development 1 (NDS1) (2020), the government of Zimbabwe has identified e-agriculture as one aspect which will boost agriculture and the economy. The NDS1 aims to deliver Internet to village level by 2030, by extending the existing fibre optic backbone. The government's strategy is to increase Internet access to $75 \%$ and the mobile penetration rate to $100 \%$ by 2025 . In its Strategic National Development 1 (NDS1) (2020), the government of Zimbabwe has identified e-agriculture as one aspect which will boost agriculture and the economy. The NDS1 aims to deliver Internet to village level by 2030, by extending the existing fibre optic backbone. The government's strategy is to increase Internet access to $75 \%$ and the mobile penetration rate to $100 \%$ by 2025 .

Waverman et al. (2005) studied the impact of mobile phones on economic growth in 92 developing countries and discovered that the impact of mobiles on economic growth in developing countries was double that of developed countries. World Bank, (2012) noted that Zambia National Farmers Union operated an SMS-based information service that provided information on commodity prices to farmers. The SMS-based information service was complimented by an electronic system which tracked transporters to and from the market. This allowed farmers to track their produce and at the same time see transporters who were available for hire. In Morocco, farmers used voice and SMS service to coordinate with local truckers to improve transport management. They succeeded to develop a two-way trade where they would deliver their products to market and bring some products back 
from the market to sell in their local communities (Dixie and Jayaraman 2011).

Sometimes farmers fail because they could not read the weather well. Sometimes they fail because they do not have adequate information about the crop they are growing. They also fail because they are unable to find or use appropriate inputs for a particular crop. They may fail because they did not get correct information about the market, or they cannot get the correct market prices for their produce, or they are being short-changed by middlemen. Crop diseases and pests are also a major cause for failure by small-scale farmers. Farming has become a more timecritical and information-intensive business. This calls for an information-based decision-making agricultural system even among small scall farmers. Farmers require the right information, at the right time and place. So, each group of farmers in a specific farming area, growing certain types of crops require specific types of information. Extension workers cannot service the farmers all the time they require assistance. Besides, Extension workers may lack certain skills to enable them to assist in some situations.

There is need for mobile and remote wireless sensors and identification technologies that can play an important role gathering data and information relevant to agricultural production, such as temperature, soil composition, and water levels (World Bank Publications, 2012). In Zimbabwe most small-scale farmers are found in remote areas. The ones in traditional small holder farms were relegated to those remote areas by the oppressive colonial system. Those resettled through the Fast-Track Land Reform programme have settled in areas where there is no infrastructure. The one technology that has surprisingly penetrated these remote areas, despite challenges, is wireless technology. It is, therefore, necessary that these farmers are backed by technologies that access the Internet using the wireless technology. Lake of information prevent farmers from making timely interventions to avoid losses from climate shocks and poor yields caused by crop diseases. Mobile phones can provide early warning systems to mitigate such risks.

Econet Zimbabwe, a Zimbabwean mobile company, has developed a mobile application called Ecofarmer. The EcoFarmer subscription platform offers farmers a package of mobile phone delivered services to increase their productivity and mitigate risk. EcoFarmer provides micro-insurance for farmers to insure inputs and crops against poor weather, such as drought or excessive rainfall. EcoFarmer has partnered with Zimbabwe Farmers' Union (ZFU) to develop EcoFarmer's Dial-a-Mudhumeni (Extension Officer) service. Using this service, farmers can call in for free to get timely farming information and advice on rearing her livestock. Farmer can also access the following information:

- Daily weather data from a weather station linked to your field.

- $\quad$ Farming and market tips

- Free daily rainfall advice

- $\quad$ Free weekly best farming prices

- $\quad$ Free weekly crop data
- Free monthly market pricing requests

- Crop information

- $\quad$ Credit rating

- $\quad$ Free adverts and marketing links

- Financial linkages

- (http://spore.cta.int/en/dossiers/article/ecofarmerbundling-information-and-financial-services.html)

The mobile applications described above show that there is a variety of mobile applications that can be implemented in agriculture. Various information requirements for the farmers seem to have been addressed by the various applications described above. Some of these applications can provide special information that can improve farming activities and outcomes.

Ericsson (2012) noted that, in some developing countries, more people have access to a mobile phone than they have to basic services such as a bank account, electricity, or clean water. In some communities the developing world some people have mobiles as their first communication gadgets. In Zimbabwe Mobile Internet and data traffic grew by $43 \%$ to record $14,878 \mathrm{~TB}$ in the third quarter of 2020 from 10,407TB recorded in the second quarter of 2020. This clearly show that mobile use is on the rise in Zimbabwe. It is important to know how small-scale farmers in Zimbabwe have factored into these statistics on mobile use.

Existing research in mobile farming in Zimbabwe is mostly concerned on what services ban be offered to small-scale farmers by mobile applications. Very little is known about what services the farmer is utilizing and the farmer's pattern of use. Very little information is available on why local mobile applications developers have not impacted on local farmers in a big way. It is important to know how small-scale farmers are embracing these mobile applications and what positive changes they have brought in the farming business.

\section{RESEARCH DESIGN AND METHODOLOGY}

For the purposes of this study, a mixture of quantitative and qualitative research methods was used. Questionnaires were distributed to 54 respondents, filled, and returned. Interviews were conducted on 10 of the respondents who had filled the questionnaire. This enabled the researcher to clarify and triangulate to verify certain data provided in the questionnaire. Tashakkori and Teddlie (2003) argue that multiple methods are useful if they provide better opportunities for the researcher to answer the research questions. The questionnaires which were distributed to the sample population allowed the researcher to collect basic data on how farmers were using their mobile phones. The questionnaire was also used because it was cost effective and suited quite well with a sample of fifty-four participants. The faceto-face interviews were conducted with 10 members who had already participated in filling the questionnaire. The results were quantified and analysed using software, thus giving objective findings. The interview was used to obtain detailed information about personal feelings, perceptions, and opinions. Interviews allowed the researcher to ask more detailed questions. 
The population for this study were all small-scale farmers in Mushandike Irrigation Scheme. Mushandike Irrigation Scheme started with a population of four hundred and twenty plot-holders. There are twenty-two villages in Mushandike irrigation scheme. The irrigation scheme was introduced as a model for small scale farmers. Irrigation infrastructure, roads and other amenities were developed before farmers were brought in. Farmers were encouraged to do intensive farming and grow crops for commercial purposes. Farmers in the irrigation scheme were targeted by this research because these farmers view farming as a business and therefore would do everything to improve their farming business. Ownership of their plots is not contested as with some newly resettled farmers. So, these were farmers who were farming without fear of being relocated or having their pieces of land repossessed.

A purposive sampling technique was used to select village 22 which is about six kilometres from the main road, and Bhuka Business Centre where base stations for Econet and Netone mobile communications companies are located. These are the major mobile service providers and many mobile phone users have subscribed to one or both. A random sampling technique was used to select the ten members who participated in the interview. Bernard (2002) noted that no amount of analysis can make up for improperly collected data. It is, therefore, important that the method, tools, and the respondents used to obtain data be selected carefully. In this research purposive sampling was used to select a village that was typical of an ideal remote rural village. The distance of six kilometres from the main road meant that these farmers needed to do more marketing to attract buyers who would otherwise settle for other farmers in villages along the main road. Agricultural extension officers lived about six kilometres away and the roads to the village were in bad state. Extension officers might find excuses for not visiting the farmers as often as they should. This means that farmers in this village must have to rely on other sources to access vital information during their farming activities. Random sampling (hat system) was used to pick members who participated in the interview because it was the fairest method in that situation. Every member had an equal chance of being picked to participate in the interview.

Questionnaires allowed the researcher to extract data from all the fifty-four plot-holders in Village 22. The questionnaire allowed all the respondents to respond to it at their own free time. This allowed respondents to complete questionnaires at their most convenient time. This could have been the reason why all the 54 respondents filled the forms, thus making the sample become more representative. The questionnaire gave enough time to respondents to recall information. Completed questionnaires were collected one week after they were delivered to respondents. The questionnaire also served time and money for the researcher in terms of travelling distance. The type of data collected using a questionnaire was easy to tabulate and analyse. Semi-structured interview questions were used in this study. These allowed the researcher to ask questions in the same way each time. There was room to alter the sequence of the questions and to probe for more information. One-on-one interviews were conducted with ten informants. The informants were free to answer the questions in any way they chose. The interviews gave the researcher a chance to triangulate in soliciting for correct information.

\section{Findings}

Table 1 provides a summary of respondents who participated in this research. 54 participants filled questionnaires, and 10 participants from the same sample responded to face-to-face interviews

Table 1: Distribution of participants by gender

\begin{tabular}{|c|c|c|c|c|}
\hline \multirow[b]{2}{*}{ Respondents } & \multicolumn{3}{|c|}{ Actual frequency } & \multirow{2}{*}{$\begin{array}{l}\text { Target } \\
\text { frequency }\end{array}$} \\
\hline & Male & Female & Total & \\
\hline $\begin{array}{l}\text { Farmers ( } \\
\text { questionnaire) }\end{array}$ & 44 & 10 & 54 & 54 \\
\hline $\begin{array}{l}\text { Farmers } \\
\text { Interview) }\end{array}$ & 8 & 2 & 10 & 10 \\
\hline
\end{tabular}

\section{Demographic Data}

Data about the age groups of participants was collected, their gender was also recorded, and the level of education was indicated. This allowed the researcher to have an insight into their intellectual capabilities. The ages of participants ranged from above 31 to above 51.18 participants were between 31 and 40 years while another 18 were between the ages of 41 and 50. 24 were above 51. Most of the participants were within the most productive age group. The information about the age groups is displayed in the table and pie chart below.

Table 2: Distribution of respondents by age group

\begin{tabular}{|l|l|}
\hline Age group & No of farmers \\
\hline $0-30$ years & 0 \\
\hline $31-40$ years & 15 \\
\hline $41-50$ years & 15 \\
\hline 51 and above & 24 \\
\hline
\end{tabular}

\section{Level of Education}

The participants were educated up to college level. Only 10 ended school at Grade 7, and 38 were secondary school graduates. Only six were college graduates. This shows that all the participants were able to read and write. This suggests they can operate a mobile phone with ease. The data about their education level is presented in the table low. No one among the respondents was educated up to degree level. This pattern might be an exhibition of earnings associated with farming and those associated with degrees and employment. For the past twenty years university graduates had struggled to find formal employment in Zimbabwe. Besides, farmers in Zimbabwe seem to earn more than graduates who are in formal employment. Therefore, these plot holders might not have found any motivation to go to university. The table and pie chart below shows the level of education of the farmers.

Table 3: Distribution of respondents by level of education

\section{Education level}

No of farmers 


\begin{tabular}{|l|l|}
\hline Primary & 10 \\
\hline Secondary & 38 \\
\hline College & 6 \\
\hline University & 0 \\
\hline None & 0 \\
\hline
\end{tabular}

shows that most farmers relied on more than one source when they want information on weather. The table and bar graph below show how information on weather is accessed by farmers.

Table 5: Sources of information on weather

\begin{tabular}{|l|l|}
\hline Source of information & No of farmers \\
\hline Extension Worker & 0 \\
\hline Radio & 45 \\
\hline Mobile phone & 13 \\
\hline Colleagues & 30 \\
\hline Other & 12 \\
\hline
\end{tabular}

\section{Sources of information on field activities}

All the 54 farmers indicated they got information on field activities from the Extension Worker. The extension work has become an integral part of the irrigation scheme since its inception. They were there to introduce new crops, new methods of farming and enforce them as per directive from government. So, it was not surprising when all of them would seek information from the extension officer. 10 selected radio as a source of information. Radio is one of the oldest communications technologies used. So, farmers expect important information to also come via the radio. The fact that only 10 farmers used radio might be a revelation that other multimedia technologies are overtaking radio. Only 12 indicated that they could also use the mobile phone. While in some other spheres of life, mobile phones have become dominant vehicles of information dissemination only $22 \%$ of the respondents used them to get vital field information. 28 chose colleagues as the source of information and 4 indicated they get information from other sources. Fellow farmers usually act as mentors to their colleagues. This could be the reason why $52 \%$ of the farmers studied rely on other farmers for field information. The table and bar graph below show how information on field activities is accessed by farmers. The data is illustrated in the table below.

Table 4: Sources of information on field activities

\begin{tabular}{|l|l|}
\hline Source of information & No of farmers \\
\hline Extension Worker & 54 \\
\hline Radio & 10 \\
\hline Mobile phone & 12 \\
\hline Colleagues & 28 \\
\hline Other & 4 \\
\hline
\end{tabular}

\section{Sources of information on weather}

All farmers indicated that they did not seek information about weather from an extension worker. This shows that farmers do not expect extension workers to have information on weather. This is because extension workers, though technical persons on the ground, did not have the tools to forecast weather. In Zimbabwe everybody seems to reply on the National Meteorological Centre for daily weather forecast. 45 indicated that they got such information from radio while 30 indicated that colleagues supplied that kind of information. The radio proved to be the main source for information needs on weather. This is because news time on national radio or television is always accompanied by a section on weather updates. Only 13 indicated that they could use the mobile phone to receive that information. Most farmers seem to have been unaware that they can also get vital information about weather from mobile phones. 12 indicated that they could use other sources. The participants' response, about acquiring information on weather, is illustrated in the table and bar chart below. This

\section{Sources of information on pests and disease}

Pests and crop diseases can wipe out crops. Al1 54 farmers indicated that they got information about pests and crop diseases from the Extension worker. The extension worker, allocated to them, is regarded as a sure source of information of crop pests and diseases. 14 indicated that radio is also a good source of information concerning this issue. Only 12 indicated that they could use a mobile phone to get such information. This shows that face to face interaction with experts was the most preferred way of getting information. Only $22 \%$ viewed mobile phones as another alternative for such information. 6 indicated that such information was obtained from other sources. 30 indicated that the information was received from colleagues. The table and bar graph below show how information on pests and diseases is accessed by farmers.

Table 6: Sources of information on pests and disease

\begin{tabular}{|l|l|}
\hline Source of information & No of farmers \\
\hline Extension Worker & 54 \\
\hline Radio & 14 \\
\hline Mobile phone & 12 \\
\hline Colleagues & 30 \\
\hline Other & 6 \\
\hline
\end{tabular}

\section{Other uses of mobile phones by farmers}

It was important to know how else farmers used their mobile phones besides the farming related tasks. All the 54 farmers indicated that they could use mobile phones for voice communications and text messages. 45 indicated that they could use the mobile phone for mobile banking. Mobile banking in this case included simple transactions such as receiving and sending money using a mobile phone. 12 indicated that that they were able to use the Internet on mobile phones. 6 indicated that they could view weather forecasts on mobile phones. 50 farmers indicated that they use their phones for social networking through Whatsup and the same number indicated that they use their mobiles for news. It was interesting to note that while $93 \%$ of the farmers studied could use their mobile phones for Whatsup and Internet not more than $24 \%$ could use their mobile phones to get information in any of the three critical areas studied. The two basic services of voice and text messages was used by all the 54 farmers. The reason could be that all mobile phones have these two functionalities. The fact that $83 \%$ of the farmers used their mobile phones for mobile banking shows that the same farmers were 
quick to embrace mobile technology when it came to banking but very few used them for mobile farming. The table below shows farmers' general use of mobile phones.

Table 7: Other uses of mobile phones by farmers

\begin{tabular}{|l|l|}
\hline Applications used & No of farmers \\
\hline Voice Communications & 54 \\
\hline Text Messages & 54 \\
\hline Internet & 12 \\
\hline Mobile banking & 45 \\
\hline Learning & 0 \\
\hline Social Networking & 50 \\
\hline News & 50 \\
\hline
\end{tabular}

\section{Data Collected using Interviews}

The face-to-face interviews gave the researcher an opportunity to verify information collected through questionnaires. The researcher wanted to find out whether their phones could access the Internet and what types of information they general get from their mobile phones. The researcher also wanted to know what type of information farmers wanted to get from their mobile phones. The farmers were also supposed to indicate the challenges they were facing in accessing information on their phones. They were also to mention any farming mobile applications they know and suggest what they think should be done to improve availability of information on mobile applications. The following questions were asked by the researcher, and the following responses were given by famers.

\section{Is your mobile phone able to access the Internet?}

One respondent was not sure if his phone could access the Internet. Maybe the respondent was one of those 4 farmers who indicated that they do not use their phone to access the internet when responding from the questionnaire. 9 interviewees said that their phones could access the Internet. This observation was similar to the one observed from the questionnaire. This shows that low mobile use was not a question of mobile phone capabilities but was because of something else.

\section{What type of information do you access on your mobile phone?}

All interviewees said that they could get messages, pictures, and videos from their phones. This was probably because these services are now a common feature of most mobile phones and most mobile users can manipulate them.

\section{What type of information would you like to be available on your mobile phone?}

The farmers wanted to know where they could sell their produce, and the prices available on the market. The farmers also wanted to know the types of pesticides they could use to attack the different diseases that attack their crops. They also wanted specifications on how to grow certain crops. $93 \%$ of the farmers had indicated on the questionnaire that they could use Internet and Whatsup on their phones. This suggest that while most of the farmers could use Internet and Whatsup, they were not able to access the information they needed.

\section{What challenges do you face in accessing information on the mobile phone?}

All the 10 farmers interviewed mentioned costs, unavailability of correct applications for farming on their phones as challenges. They also said that they did not have the know-how to install some applications on their phones.

\section{Give suggestions on what should be done to improve availability of information on mobile phones}

Farmers thought farming mobile applications should be made available to farmers free of charge to promote farming and improve food security in the country. They also suggested that they should be trained on how to manipulate their handsets, to enable them to access the information they require for their farming business. They wanted to be able to market their farm produce using their phones and be able to locate and buy inputs online.

\section{Conclusion}

Farmers barely used mobile phones to access information that would help them in their field work. Farmers preferred to use extension workers because they did not view their mobile phones as another source of information. This shows that farmers were unaware about the capabilities of the mobile phones to give weather forecasts. The main source of information when it comes to dealing with traditional issues such as pests and crop diseases was the Extension Officer. More research should be done to find out why there is such a low adoption of mobile phones as gargets to enhance agriculture in Zimbabwe. 


\section{References}

Bernard H, R. (2002) Research methods in anthropology: Qualitative and quantitative approaches. 3rd Alta Mira Press; Walnut Creek, CA: [Google Scholar]

Dixie, G., Jayaraman, N., 2011. Strengthening agricultural marketing with ICT. The World Bank/InfoDev'ARD, ICT in agriculture: connecting smallholders to knowledge, networks, and institutions. Module 9, pp.205-237.

EcoFarmer, Agribusiness Services, https://www.ecofarmer.co.zw/dial-amudhumeni

Gichamba, A. and I.A. Lukanda. 2012. "A Model for Designing M-Agriculture Applications for Dairy Farming.” African Journal of Information Systems 4(4) http://digitalcommons.kennesaw.edu/ ajis/vol4/iss4/1/.

Musungwini, S. (2018). Mobile phone use by Zimbabwean smallholder farmers: A baseline study. The African Journal of Information and Communication (AJIC), 22, 29-52. https://doi.org/10.23962/10539/26171

Parrish BD, Luzadis VA, Bentley, WR (2005). What Tanzania's coffee farmers can teach the world: A performance-based look at the fair trade-free trade debate. Sustain. Develop, 13:177-189.http://dx.doi.org/10.1002/sd.276

Postal and Telecommunications Regulatory Authorities of Zimbabwe 2020, Telecommunications Sector Performance Report: Third Quarter 2020

Republic of Zimbabwe, 2020, Strategic National Development 1 2021-2025 (NDS1)

Richard A. Duncombe R, A (2014) Understanding the Impact of Mobile Phones on Livelihoods in Developing Countries, Development Policy Review, Volume32, Issue 5

Tashakkori, A. \& Teddlie, C. (2003). Handbook of Mixed Methods in Social \& Behavioral Research. Thousand Oaks: Sage.

Waverman, L., Meschi, M., \& Fuss, M. (2005). The impact of telecoms on economic growth in developing countries. The Vodafone Policy Paper Series, 2, 10-23. Available at:

http://www.vodafone.com/content/dam/vodafone/about/public_policy/policy_pap ers/public_policy_series_2.pdfGoogle Scholar

World Bank, 2011, ICT IN AGRICULTUREC: Connecting Smallholders to Knowledge, Networks, and Institutions, http://documents1.worldbank.org/curated/en/455701468340165132/pdf/646050E $\underline{\text { SW0P1180lture0e0Sourcebook12.pdf }}$ 